\title{
PEMODELAN SEBARAN SEDIMEN TERSUSPENSI DAMPAK PENAMBANGAN TIMAH DI PERAIRAN BANGKA
}

\section{THE MODELLING OF SUSPENDED SEDIMENT DISTRIBUTION DUE TO TIN MINING IN BANGKA SEAS}

\author{
Aditya Pamungkas $^{1 *}$ \& Semeidi Husrin ${ }^{2}$ \\ ${ }^{1}$ Program Studi Ilmu Kelautan, Fakultas Pertanian Perikanan dan Biologi, \\ Universitas Bangka Belitung, 33126, Indonesia \\ ${ }^{2}$ Pusat Penelitian dan Pengembangan Sumber Daya Laut dan Pesisir, \\ Kementerian Kelautan dan Perikanan, Jakarta, 14430, Indonesia \\ *E-mail: aditya.pamungkas.ubb@gmail.com
}

\begin{abstract}
Bangka Island is the largest offshore tin mining in Indonesia conducted by companies and local communities, both legal and illegal. This could be alarming, for example Kelabat Bay which planned as a conservation area due to the impact of increase of suspended solid. This research aims to analyze the hydro-oceanographic conditions and Total Suspended Solid (TSS) distribution process due to tin mining in Bangka Waters, especially in Kelabat Bay. The method used was numerical modelling using MIKE 21 software to obtain hydro-dynamics data and TSS distribution due its sources from each mining spot with Flow Model Flexibel Mesh (FM) module and Mud Transport (MT) module. The model's verification obtained 0.9435 correlation and 0.1611 Root Mean Squared Error (RMSE) for tidal data. The tailing will cause high TSS distribution in Bangka Waters especially for mining activities in shallow waters $(<10 \mathrm{~m})$ and nearby coast $(<2$ miles). The distribution of TSS in Bangka Waters will be dominantly carried towards the Bangka Strait. In Kelabat Bay itself, the TSS value is 0$25 \mathrm{mg} / \mathrm{L}$ and spread throughout the region with radius around 16 miles. The Bangka Waters, especially Kelabat Bay which planned as conservation area will be threatened by the increase of TSS due to offshore mining activities. It will become the recommendation for policy making in Bangka Belitung such as coastal and small islands zoning policy.
\end{abstract}

Keywords: Bangka Belitung, numerical modelling, tin mining, TSS

\begin{abstract}
ABSTRAK
Pulau Bangka merupakan penambangan timah lepas pantai terbesar di Indonesia yang dilakukan oleh perusahan dan masyarakat, baik legal maupun ilegal. Hal ini menjadi mengkhawatirkan terutama akan dampaknya terhadap peningkatan sedimentasi, seperti wilayah Teluk Kelabat yang direncanakan menjadi kawasan konservasi. Tujuan penelitian ini adalah mengetahui kondisi hidro-oseanografi dan sebaran Total Suspended Solid (TSS) akibat penambangan timah di perairan Bangka terutama di Teluk Kelabat. Metode yang digunakan adalah analisis pemodelan numerik dengan menggunakan software MIKE21 untuk memperoleh data hidro-oseanografi dan model sebaran TSS dengan sumber TSS dari tiap-tiap lokasi Izin Usaha Pertambangan (IUP) melalui modul Flow Model Flexibel Mesh (FM) dan Mud Transport (MT). Verifikasi hasil model diperoleh korelasi sebesar 0,9435 dengan Root Mean Squared Error (RMSE) sebesar 0,1611 untuk pasang-surut. Tailing penambangan timah lepas pantai akan menyebabkan tingginya sebaran TSS di perairan Bangka, terutama aktivitas penambangan di perairan yang dangkal $(<10 \mathrm{~m})$ dan dekat pesisir $(<2$ mil). Sebaran TSS di perairan Bangka akan dominan terbawa ke arah Selat Bangka. Pada Teluk Kelabat, TSS bernilai sekitar 0-25 mg/L dan menyebar ke seluruh wilayah yang dapat mencapai radius sekitar 16 mil. Hasil penelitian ini diharapkan dapat menjadi rekomendasi bagi stakeholder seperti penyusunan Rencana Zonasi Pesisir Dan Pulau-Pulau Kecil (RZWP3K) di Bangka Belitung.
\end{abstract}

Kata kunci: Bangka Belitung, pemodelan numerik, penambangan timah, TSS 


\section{PENDAHULUAN}

Wilayah Provinsi Kepulauan Bangka Belitung merupakan produsen timah terbesar di Indonesia. Saat ini, kegiatan penambangan timah di Bangka telah bergeser dari penambangan di darat beralih ke penambangan lepas pantai, terutama di wilayah pesisir. Kegiatan penambangan timah ini dilakukan oleh berbagai pihak baik perusahaan besar (seperti PT. Timah, Tbk.) (Yustiani et al., 2012) maupun oleh masyarakat sekitar yang seringkali ilegal. Fenomena ini mengakibatkan banyak daerah di perairan Bangka rusak oleh kegiatan penambangan lepas pantai.

Sebagai contoh, salah satu daerah yang meningkat terjadi aktivitas penambangan timah lepas pantai adalah Teluk Kelabat (Yustiani et al., 2012). Teluk Kelabat merupakan perairan yang terletak di bagian utara pulau Bangka dan menghadap langsung ke laut Natuna. Secara geografis, Teluk Kelabat merupakan perairan semi tertutup yang terdiri dari dua wilayah Teluk Kelabat bagian dalam dan luar yang dipisahkan dengan 'celah' yang sempit dan dangkal (Sachoemar \& Kristijono, 2007). Dalam sepuluh tahun terakhir, pemerintah Provinsi Bangka Belitung mengembangkan Teluk Kelabat sebagai kawasan terpadu pengembangan perikanan dan kelautan (Arifin, 2011). Selain itu, Teluk Kelabat sendiri juga merupakan kawasan konservasi berdasarkan rancangan RZWP3K di tahun 2018. Kondisi inilah yang menjadikan perairan Bangka, khususnya Teluk Kelabat dan bagian lain perairan Bangka harus dikelola dengan baik dalam pelestariannya, terutama dari ancaman kegiatan penambangan timah lepas pantai.

Aktivitas penambangan timah, baik di darat maupun lepas pantai akan berdampak bagi ekosistem di sekitarnya. Secara umum, dampak penambangan timah diantaranya akan meningkatkan kekeruhan air (Susiati et al., 2010), pendangkalan (Solihuddin et al., 2011), dan mengancam ekosistem pesisir (Rachman et al., 2016), utamanya disebabkan oleh sedimentasi yang berlebihan (Sachoemar \& Agus, 2005; Yustiani et al., 2012). Tujuan dari penelitian ini adalah untuk mengetahui dampak penambangan timah lepas pantai yang disebabkan oleh sebaran TSS di perairan Bangka. Penelitian ini juga akan fokus pada perairan Teluk Kelabat sebagai kawasan konservasi untuk mendapatkan pemahaman yang baik tentang efek sedimentasi akibat penambangan timah. Hasil penelitian ini akan memberikan gambaran yang komprehensif tentang dampak penambangan timah lepas pantai di perairan Bangka sehingga dapat dijadikan sebagai acuan bagi para pemangku kepentingan untuk membuat keputusan terkait rencana pengelolaan pesisir dan pulau-pulau kecil secara berkelanjutan.

\section{METODE PENELITIAN}

\subsection{Waktu dan Lokasi}

Lokasi penelitian dilakukan di perairan Bangka, Provinsi Bangka Belitung. Penelitian ini juga akan fokus mengkaji Teluk Kelabat (Figure 1) yang merupakan kawasan konservasi untuk dapat melihat lebih jauh dampak penambangan timah lepas pantai. Tahapan penelitian ini terbagi menjadi pengumpulan data awal, survei lapangan, pembuatan model dan analisis. Survei lapangan dilaksanakan pada Juli dan Agustus 2019 yang mengambil beberapa data untuk penelitian ini. Data tersebut kemudian digunakan sebagai input (masukan) dan validasi hasil model yang digunakan untuk melihat efek sedimentasi akibat penambangan timah. Penelitian ini memfokus pada banyaknya sebaran TSS akibat penambangan timah di perairan Bangka.

\subsection{Metode Pengumpulan Data}

Pengumpulan data lapangan difokuskan pada pengukuran kondisi hidrooseanografi termasuk arus, pasang-surut, 


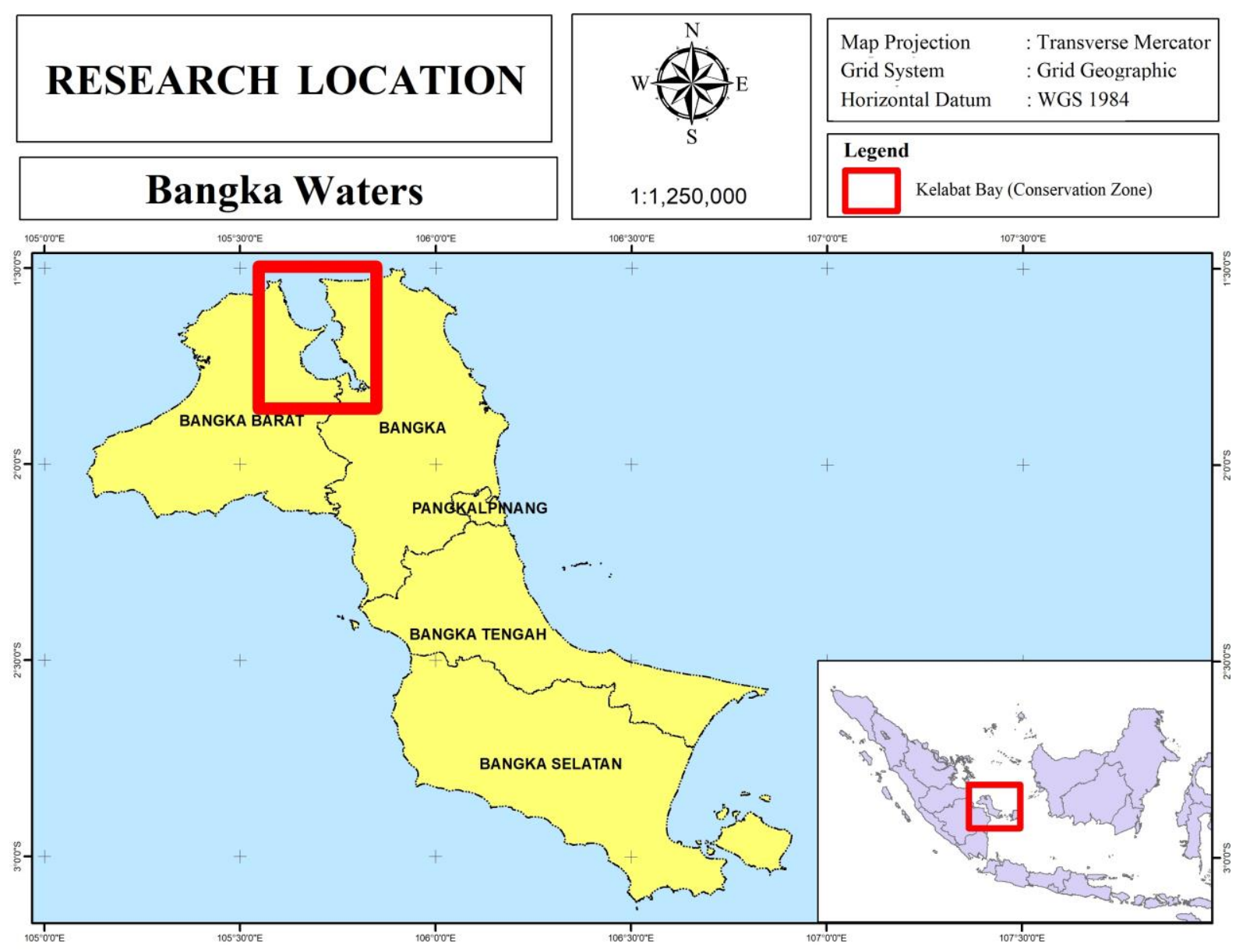

Figure 1. Research location and focused area (red box), Kelabat Bay as conservation zone.

gelombang, batimetri, TSS dan laju sedimentasi yang digunakan sebagai data dasar dalam pemodelan numerik. Selain itu, penelitian ini juga menggunakan data sekunder seperti peta batimetri dari Dinas Hidrografi dan Oseanografi Angkatan Laut (DISHIDROS TNI-AL), data pasang surut dari Babel Ocean Observation Science and Technologies (BOOST) Center dan beberapa data klimatologi dari European Centre for Medium-Range Weather Forecasts (ECMWF) melalui https://apps.ecmwf.int/ datasets/data/interim-full-daily/ sebagai atmospheric forcing yang meliputi kecepatan angin dan tekanan udara untuk pembuatan model numerik.

\subsection{Metode Pemodelan Numerik}

Pemodelan numerik adalah salah satu metode untuk mengetahui kondisi hidro- dinamika yang diduga memengaruhi penyebaran polutan di suatu perairan (Rachman et al., 2016). Penelitian ini menggunakan metode pemodelan numerik selama 1 tahun penuh yang meliputi pasang surut, gelombang, arus, dan juga distribusi sedimen dari total padatan tersuspensi, dikerjakan dengan metode pemodelan numerik. Model yang digunakan dalam penelitian ini adalah pemodelan 2-dimensi (2D) menggunakan MIKE21. MIKE21 adalah model yang dikembangkan oleh DHI yang menggunakan sistem grid Arakawa $\mathrm{C}$ dan koordinat sigma (DHI, 2005). Model ini memiliki persamaan kontinuitas dan momentum sebagaimana merujuk pada manualnya sebagai persamaan pembangun hidrodinamikanya.

Penelitian ini menggunakan 2 modul dalam MIKE21 yakni modul Flow Model Flexibel Mesh (FM) dan modul Mud 
Transport (MT). Hasil modul FM diperoleh data hidrodinamika yang kemudian digunakan pada dalam modul MT untuk melihat sebaran TSS dampak aktivitas penambangan timah lepas pantai.

Model distribusi sedimen ini membutuhkan lokasi dan nilai tailing dari sumber penambangan timah. Dalam penelitian ini, titik lokasi sumber TSS merupakan perwakilan area IUP yang ada di perairan Bangka (Figure 2). Total terdapat 25 titik lokasi sumber TSS sebagai akibat dari buangan (tailing) penambangan timah. Selanjutnya, pada tiap titik sumber tailing tersebut diasumsikan mengeluarkan TSS sebesar $500 \mathrm{mg} / \mathrm{L}$ berdasarkan estimasi kapasitas kapal keruk dan beroperasi secara kontinu (Yustiani et al., 2012). Pada penelitian ini proses sebaran TSS dikaji selama 1 bulan, 3 bulan, 6 bulan dan 1 tahun. Hal ini dilakukan untuk melihat bagaimana pola arus, baik pada musim barat dan timur berperan dalam penyebaran partikel tersuspensi akibat penambangan timah lepas pantai.

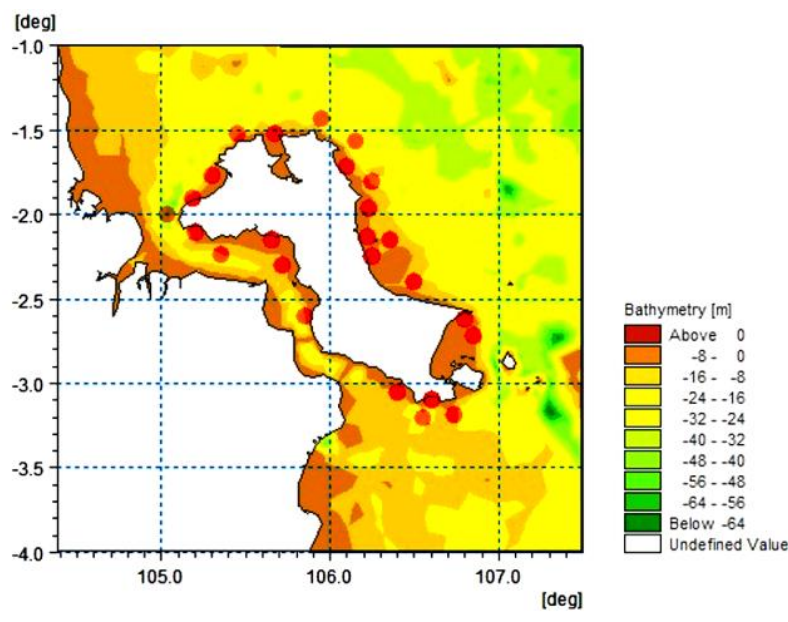

Figure 2. Source points of TSS from offshore tin mining activities (dot represent tin mining area permit in Bangka Waters).

Pemodelan memerlukan tahapan verifikasi untuk menguji tingkat kepercayaan dan penyimpangan hasil simulasi (Rachman et al., 2016). Oleh karena itu, data pasang- surut pada model akan dibandingkan dengan data survei lapangan. Selain itu, data TSS hasil survei lapangan juga akan dibandingkan dengan hasil model modul MT dari MIKE21.

\section{HASIL DAN PEMBAHASAN}

\subsection{Pasang-Surut}

Perairan Bangka Belitung memiliki tipe pasang-surut diurnal dengan tunggang pasut berkisar 0-2 $\mathrm{m}$. Pasang surut berperan penting untuk menghasilkan arus terutama di perairan semi tertutup seperti Teluk Kelabat (Pamungkas dan Arthur, 2019). Pasang-surut juga merupakan salah satu komponen gaya pembangkit (forcing) dalam pembuatan model hidrodinamika di penelitian ini. Oleh karena itu, pengukuran pasang surut dilakukan di Teluk Kelabat untuk menguji keakuratan model yang digunakan. Perbandingan antara data pasang surut hasil survei dengan model disajikan pada Figure 3.

Berdasarkan hasil perbandingan antara data lapangan dan data model diperoleh nilai korelasi antara kedua data tersebut, yaitu 0,9435 dengan RMSE sebesar 0,1611. Nilai korelasi tersebut menunjukan data lapangan dan model memiliki kesamaan fase pasang surut sedangkan nilai RMSE membuktikan data pada model cukup baik digunakan dalam penelitian ini. Pergerakan arus pasang-surut ini akan dominan dalam penyebaran TSS di suatu perairan (Solihuddin et al., 2011) yang disertai oleh faktor pendukung lainnya seperti arus sejajar pantai, gelombang dan sebagainya. Selanjutnya, pasang surut dan gaya pembangkit lainnya akan menghasilkan model hidrodinamika yang akan digunakan untuk melihat sebaran TSS (Sukarno \& Yusuf, 2013) akibat aktivitas penambangan timah lepas pantai.

\subsection{Pola Pergerakan Arus}

Arus di suatu perairan akan berperan sangat penting untuk mengkaji pola sebaran TSS dampak penambangan timah lepas 


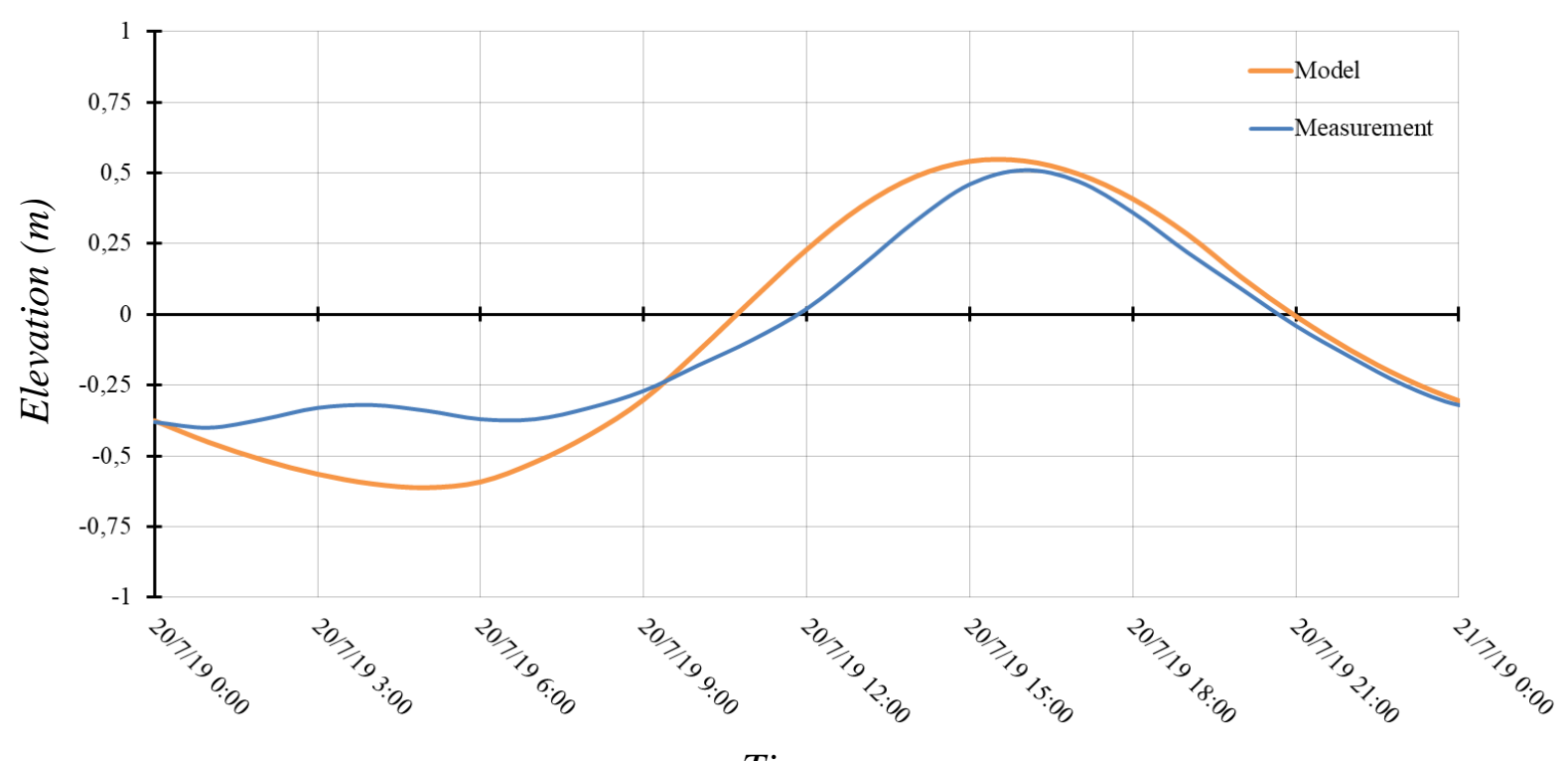

Time

Figure 3. Verification between model (orange line) and field data (blue line) on Juli $20^{\text {th }}$, 2020.

pantai. Pola pergerakan arus di Laut Bangka yang menghubungkan Samudera Pasifik dan Hindia (Hartoko et al., 2019) akan cenderung mengikuti aliran Arus Lintas Indonesia (Pamungkas et al., 2017) dan sangat dipengaruhi oleh angin monsoon (Ambalika et al. 2019). Pada musim Barat, arus perairan Bangka dominan mengalir dari Laut Natuna ke Laut Jawa (Figure 4). Kondisi ini disebabkan oleh arah angin pada musim Barat yang bergerak dari Benua Asia ke Benua Australia (Pamungkas et al., 2019). Saat monsun Barat, kecepatan arus di perairan Bangka berkisar 0,6 m/s. Pola arus mengalir melalui dua jalur utama yaitu Selat Bangka di sebelah Barat dan Selat Gaspar di sebelah Timur Pulau Bangka. Arus di Selat Bangka cenderung lebih tinggi disebabkan oleh lebih sempit dan dangkalnya perairan ini (Ambalika et al., 2019).

Sebaliknya pada musim timur, arus di perairan Bangka dominan mengalir dari Laut Jawa ke Laut Natuna (Figure 4). Ketika musim timur, arah angin berkebalikan dengan musim barat yakni angin akan bergerak dari Benua Australia ke Benua Asia (Pamungkas, 2018). Hal ini menye- babkan arus bergerak dalam arah yang sama. Ketika musim timur, kecepatan arus di Laut Bangka cenderung lebih rendah daripada musim Barat. Kecepatan arus di Laut Bangka pada musim Barat berkisar 0,3 m/s.

Pola arus di perairan Bangka sangatlah dipengaruhi oleh kondisi angin monsun, tidak seperti perairan Pelabuhan Ratu (Setyawan \& Pamungkas, 2017) dan Teluk Kelabat yang sangat dipengaruhi oleh kondisi geografis dan pasang-surut. Teluk Kelabat terdiri dari dua bagian yaitu Teluk Kelabat Luar (TKL) dan Teluk Kelabat Dalam (TKD) dan dipisahkan oleh perairan sempit dan dangkal (Figure 1). Pamungkas \& Farhaby (2019) menjelaskan bahwa Teluk Kelabat dapat dikategorikan sebagai perairan semi-tertutup yang sangat dipengaruhi kondisi pasang-surut.

Pada kondisi menuju pasang, arus bergerak dari TKL memasuki TKD dan sebaliknya ketika kondisi menuju surut (Figure 5). Dibandingkan faktor angin monsoon, pola arus di perairan Teluk Kelabat lebih dominan dipengaruhi oleh kondisi pasang-surut. Kecepatan arus di Teluk Kelabat dapat mencapai $1.3 \mathrm{~m} / \mathrm{s}$ di 


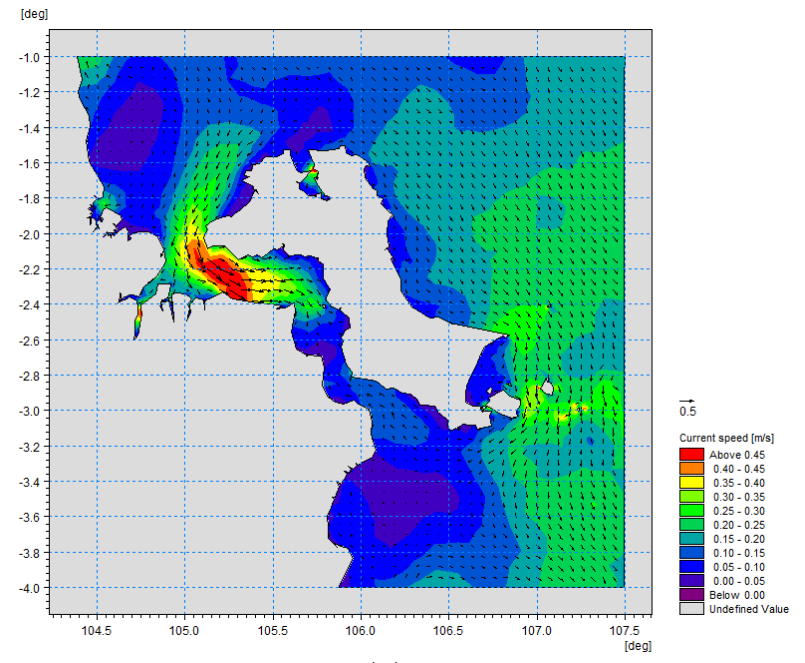

(a)

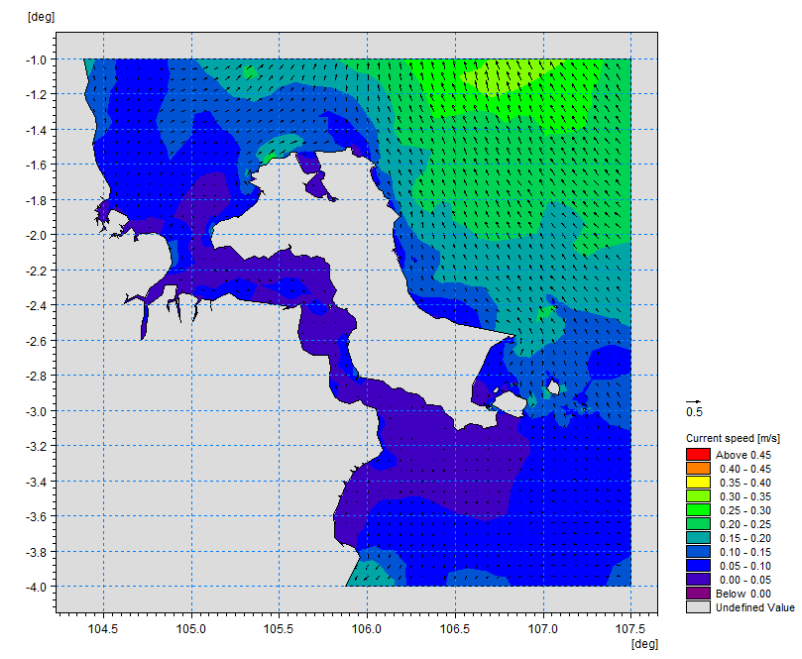

(b)

Figure 4. Current pattern at Bangka Waters on (a) West Monsoon dan (b) East Monsoon.

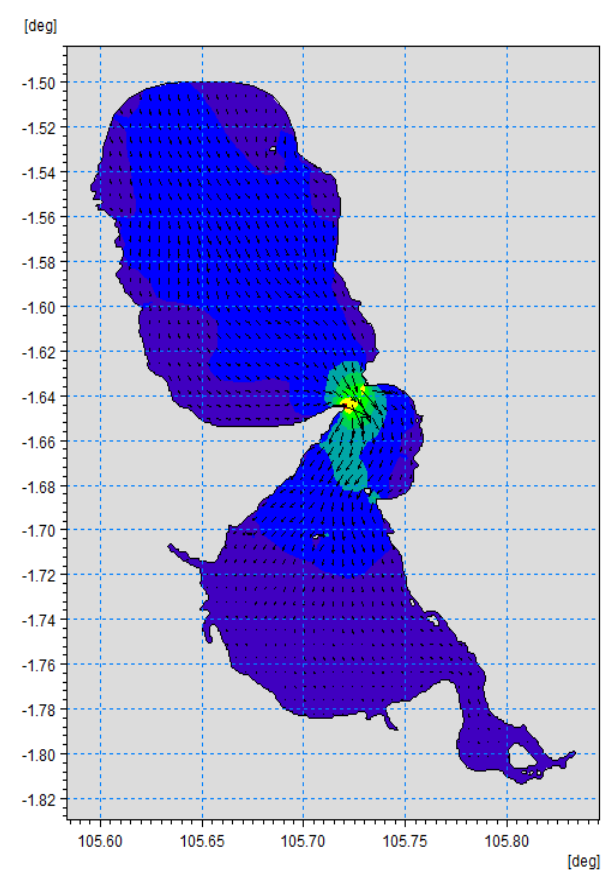

(a)
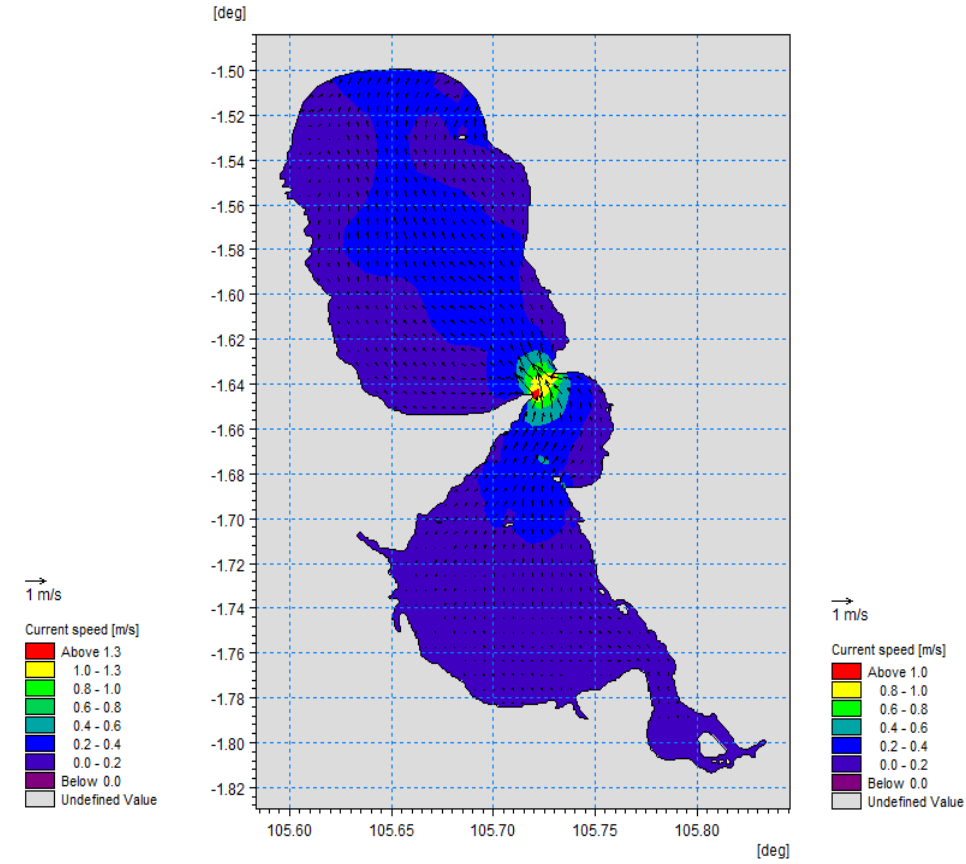

(b)

Figure 5. Current pattern at Kelabat Bay on (a) toward high tide, and (b) toward low tide.

area pemisah TKD dan TKL. Pola yang sama terjadi di Teluk Benoa (Rachman et al., 2016) dan Teluk Ambon (Fadli \& Radjawane, 2013), arus mengalir dari bagian luar ke dalam teluk ketika menuju pasang dan sebaliknya ketika menuju surut dengan kecepatan arus berkisar antara $0-1.463 \mathrm{~m} / \mathrm{s}$ (Ondara et al., 2017). Pada wilayah TKD dan TKL kecepatan arus relatif lemah berkisar antara $0-0,4 \mathrm{~m} / \mathrm{s}$.

\subsection{Pola Sebaran TSS}

Setelah mengetahui pola arus melalui hasil pemodelan hidrodinamika, pemodelan sebaran TSS dilakukan dengan menggunakan modul Mud Transport pada MIKE21 
dan hasilnya disajikan pada Figure 6. Pada 1 bulan pertama peningkatan sebaran TSS belum terlihat signifikan di perairan Bangka. Hanya beberapa titik yang telah terlihat sebaran TSS yang signifikan yakni 1 titik di Barat (sekitar Tj. Resang), 1 titik di Selatan (sekitar Toboali) dan 1 titik di Timur (sekitar Pangkalpinang-Koba) Perairan Bangka dengan kisaran 0-18 mg/L (Figure 2). Ketiga titik sumber IUP tersebut merupakan titik aktivitas penambangan timah lepas pantai yang berada di perairan dengan kondisi dangkal (kedalaman $<10 \mathrm{~m}$ ) dan dekat pantai (jarak dengan pantai $<2$ mil). Kondisi perairan seperti ini merupakan daerah yang sangat rawan tercemar tailing penambangan timah lepas pantai dikarenakan TSS akan cenderung terbawa arus dan gelombang ke arah pesisir dan bergerak tersebar menyusur pantai (Sukarno \& Yusuf, 2013). Sedangkan nilai TSS akan semakin rendah ke arah laut (Nugroho et al., 2016).

Setelah 3 hingga 6 bulan, telah ter- dapat banyak bagian perairan Bangka yang telah melewati Baku Mutu Air Laut (BMAL) akibat adanya sebaran TSS dampak tailing penambangan timah lepas pantai. Kondisi ini menunjukkan bahwa tailing penambangan timah lepas pantai akan memengaruhi perairan tersebut serta dapat terbawa menuju perairan lain di sekitarnya. Setelah 1 tahun dilakukan simulasi, sebaran TSS dominan akan terpindahkan oleh arus dan terbawa ke perairan Selat Bangka.

Pada Figure 7 dapat terlihat bahwa TSS di perairan Bangka akan cenderung lebih tinggi di sebelah barat Pulau Bangka (Selat Bangka) dibandingkan dengan Selat Gaspar di sebelah timur Pulau Bangka. Banyaknya TSS di perairan tersebut dipengaruhi juga oleh pola arus akibat angin monsoon (Sugiyatno, 2009) dan pasokan sedimen tersuspensi (Susianto et al., 2010) yang dalam kasus ini bersumber dari tailing penambangan timah lepas pantai (Sugiyatno, 2009).

(a)

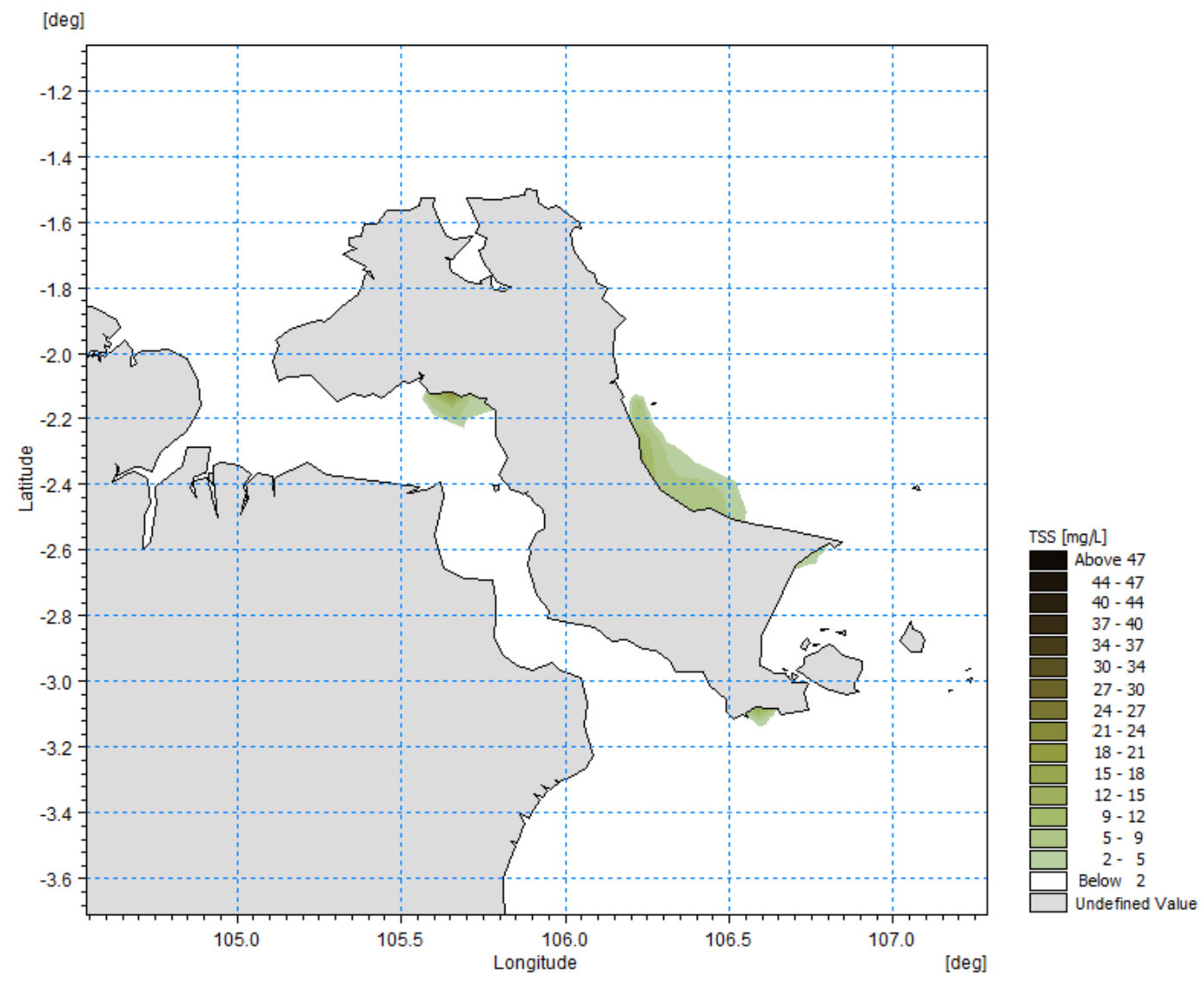


(b)
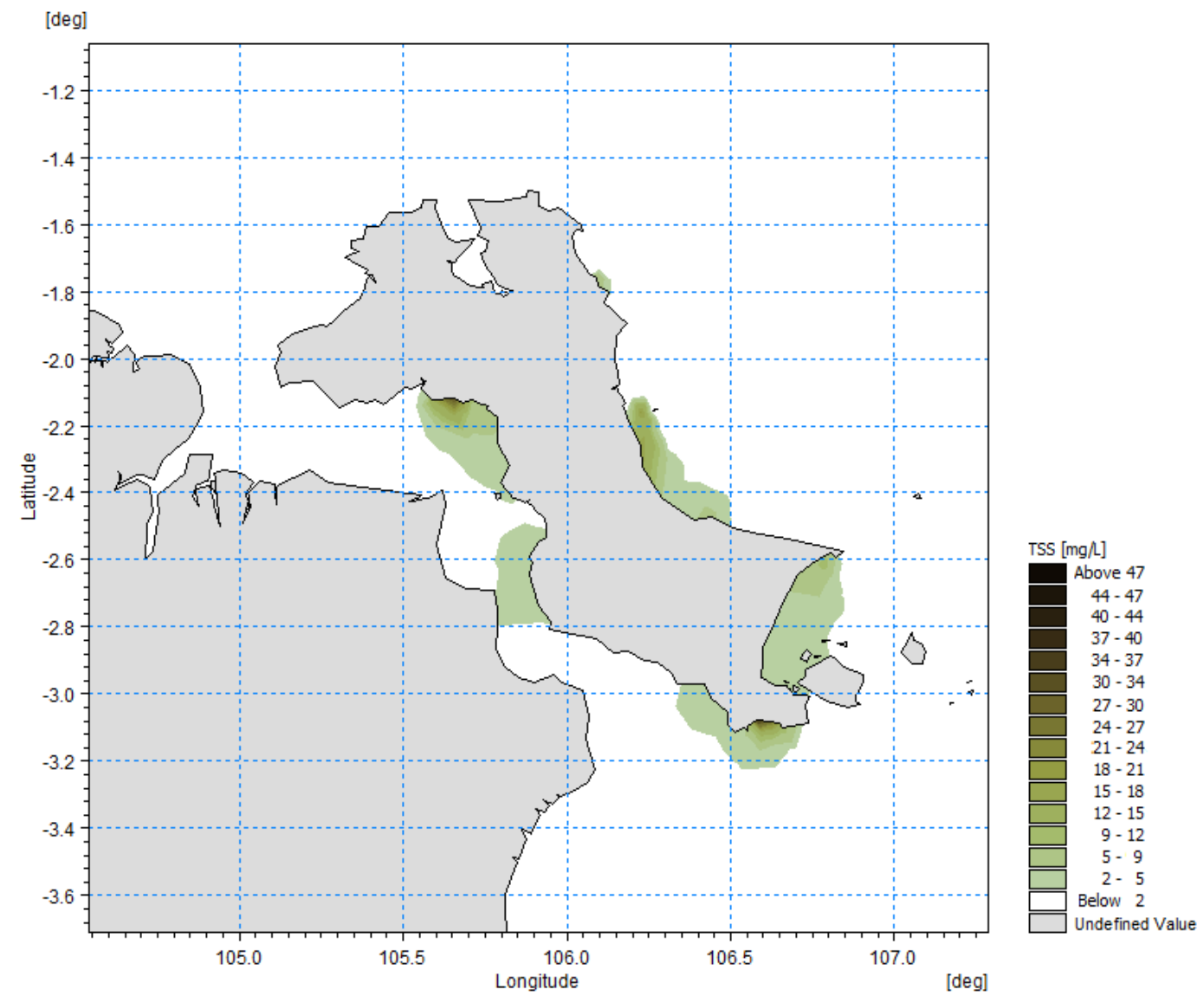

(c)

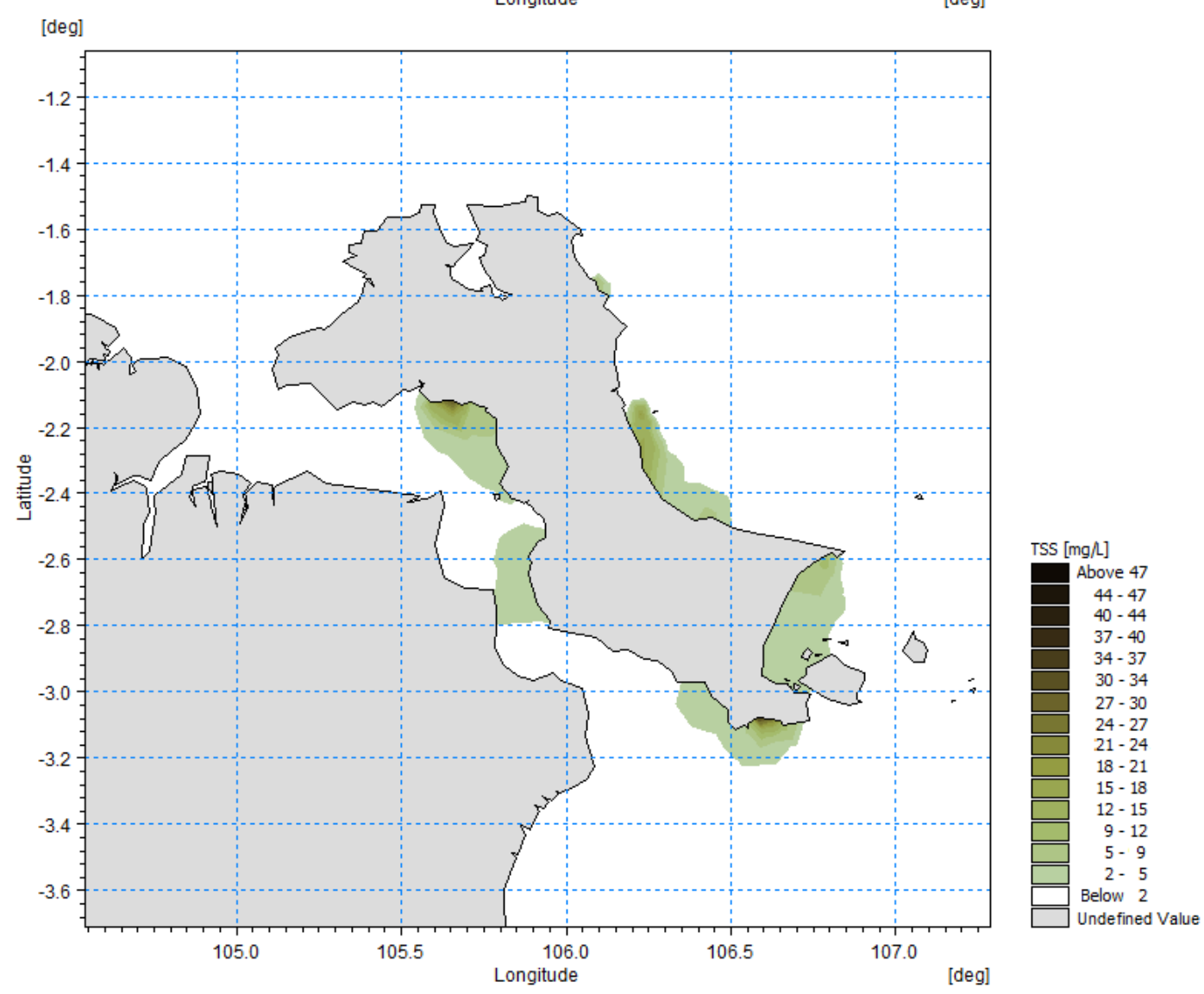


(d)

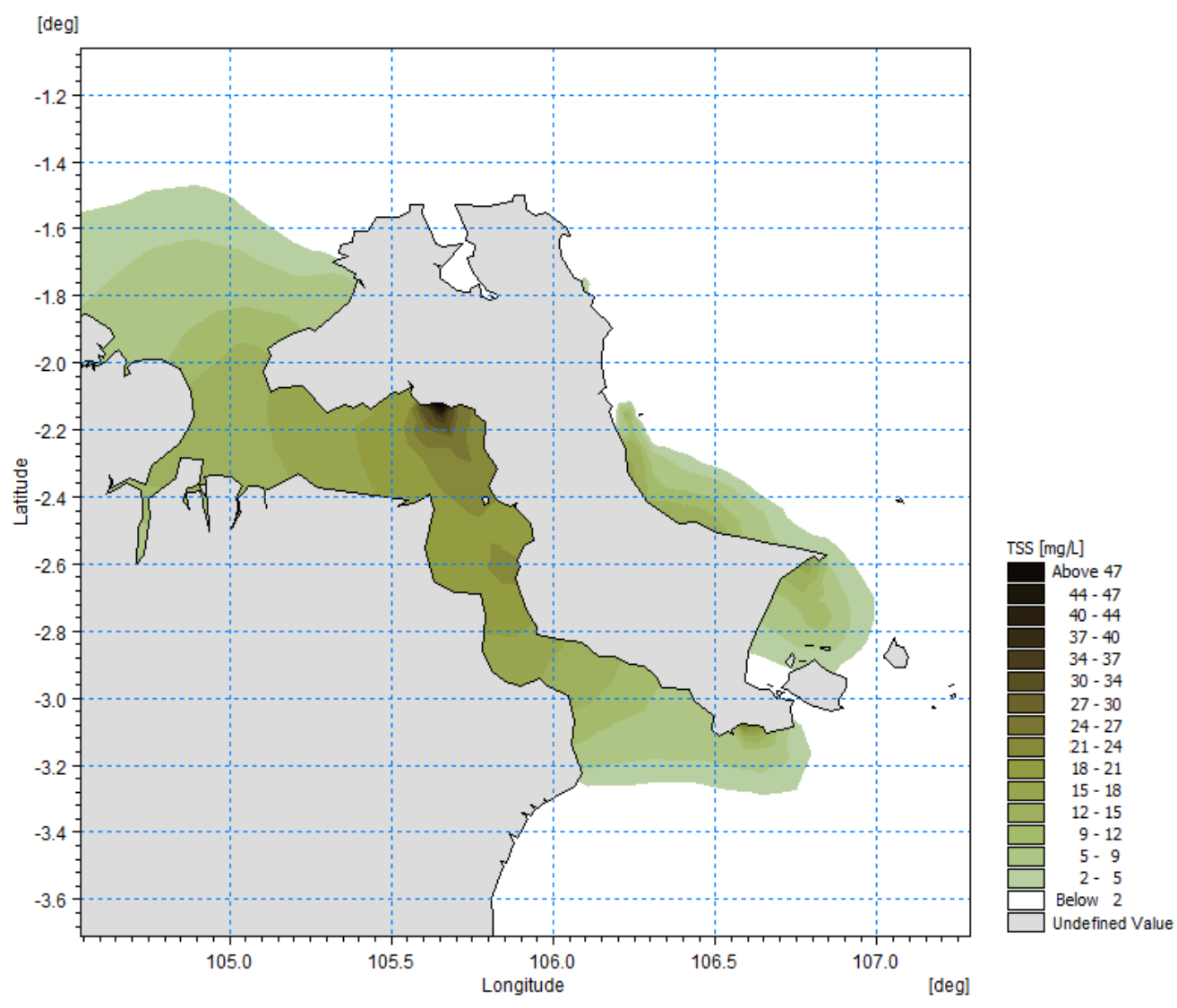

Figure 6. TSS distribution on Bangka Waters for a) 1 month, b) 3 months, c) 6 months and d) 1 year (white colour: TSS still under sea water quality standarts).

Sebagai bagian dari perairan Bangka, perairan Teluk Kelabat memiliki sumber TSS yang terletak pada batas terluar Teluk Kelabat akibat proses tailing penambangan timah (batas utara pada kotak merah). Pola sebaran TSS di Teluk Kelabat disajikan pada Figure 7 selama 1 bulan, 3 bulan, 6 bulan dan 1 tahun. Berdasarkan hasil pemodelan diketahui bahwa tailing akibat aktivitas pertambangan akan menyebabkan penyebaran TSS yang terus meluas sepanjang waktu. Berbeda halnya dengan perairan Bangka yang merupakan perairan terbuka, Teluk Kelabat sebagai perairan semi-tertutup akan dominan menyebarkan TSS ke arah TKD akibat pengaruh arus pasang-surut yang membawa sedimen tersuspensi tersebut (Rachman et al., 2016).

Sebaran TSS tersebut berkisar antara 0-25 mg/L dan tersebar hingga radius $(\sim 16$ mil dari lokasi IUP). Hal ini dapat mem- perlihatkan bahwa apabila IUP di luar Teluk Kelabat beroperasi akan menyebabkan semakin keruh dan meningkatnya TSS hingga di bagian paling dalam Teluk Kelabat. Kondisi ini akan memengaruhi zona-zona lain yang berada di Teluk Kelabat antara lain zona konservasi, perikanan tangkap dan perikanan budi daya. Sehingga diperlukan solusi untuk meminimalisir dampak tersebut antara lain dengan melakukan eksploitasi secara bertahap hingga menggunakan teknologi pertambangan ramah lingkungan.

Apabila kita bandingkan dengan data hasil pengukuran lapangan, TSS di perairan Teluk Kelabat berkisar diantara 27,5-28,0 $\mathrm{mg} / \mathrm{L}$ (Table 1). Hasil pengukuran ini memiliki nilai yang cenderung lebih tinggi dibandingkan dengan hasil model berkisar antara 23-25 mg/L (Table 1) akan tetapi lebih rendah apabila dibandingkan dengan 
Pemodelan Sebaran Sedimen Tersuspensi Dampak Penambangan ...

(a)

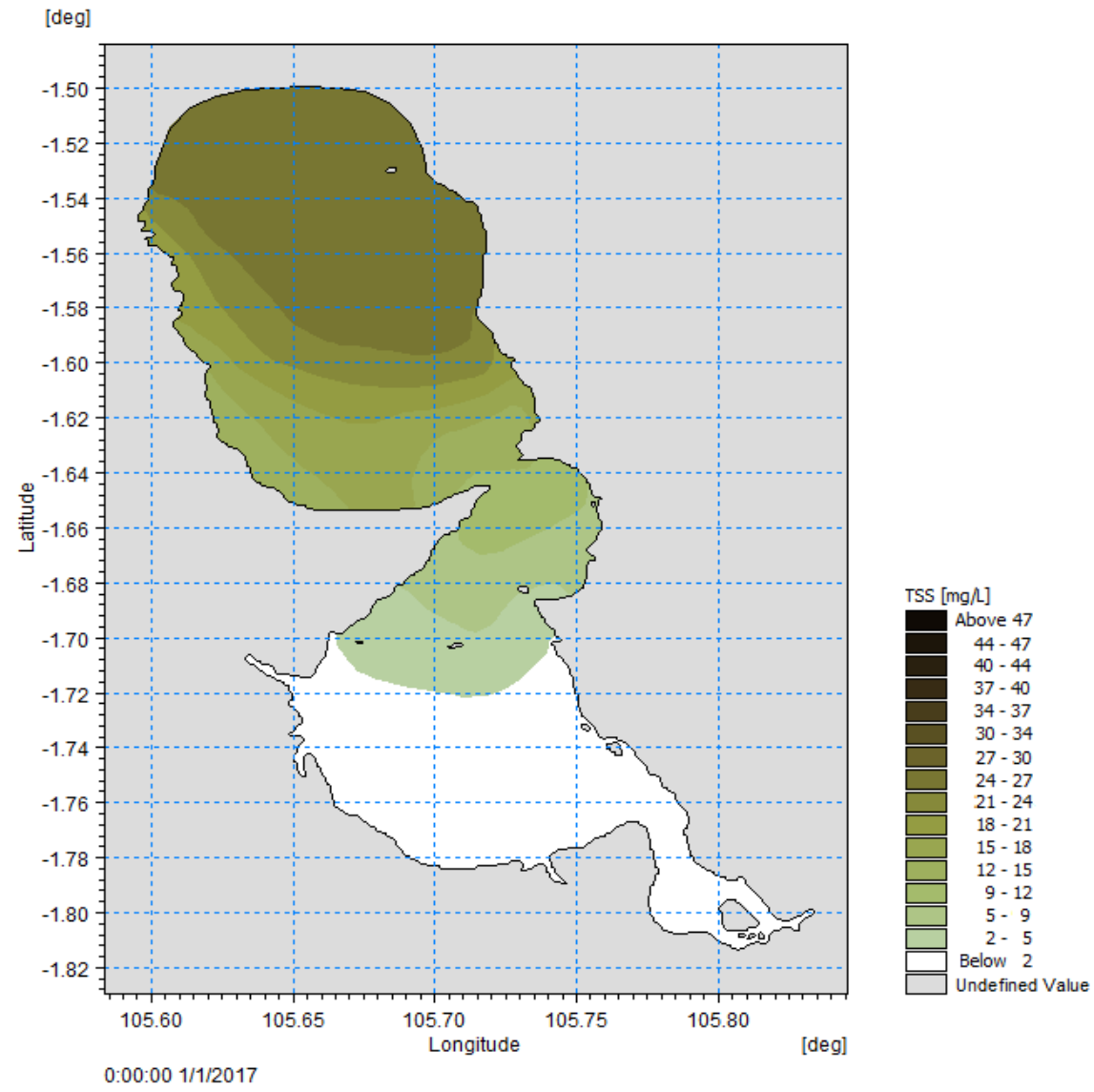

(b)

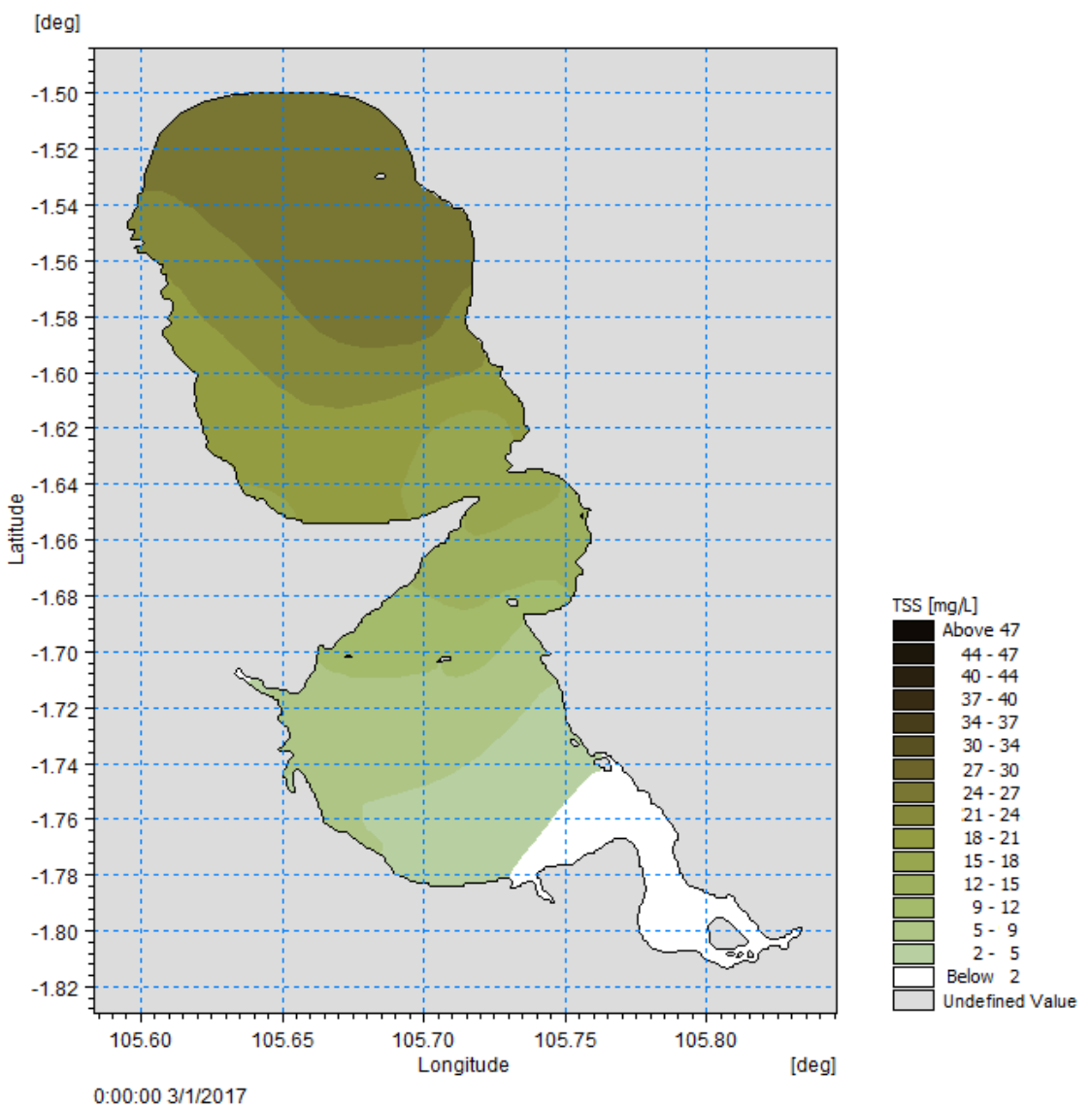


(c)

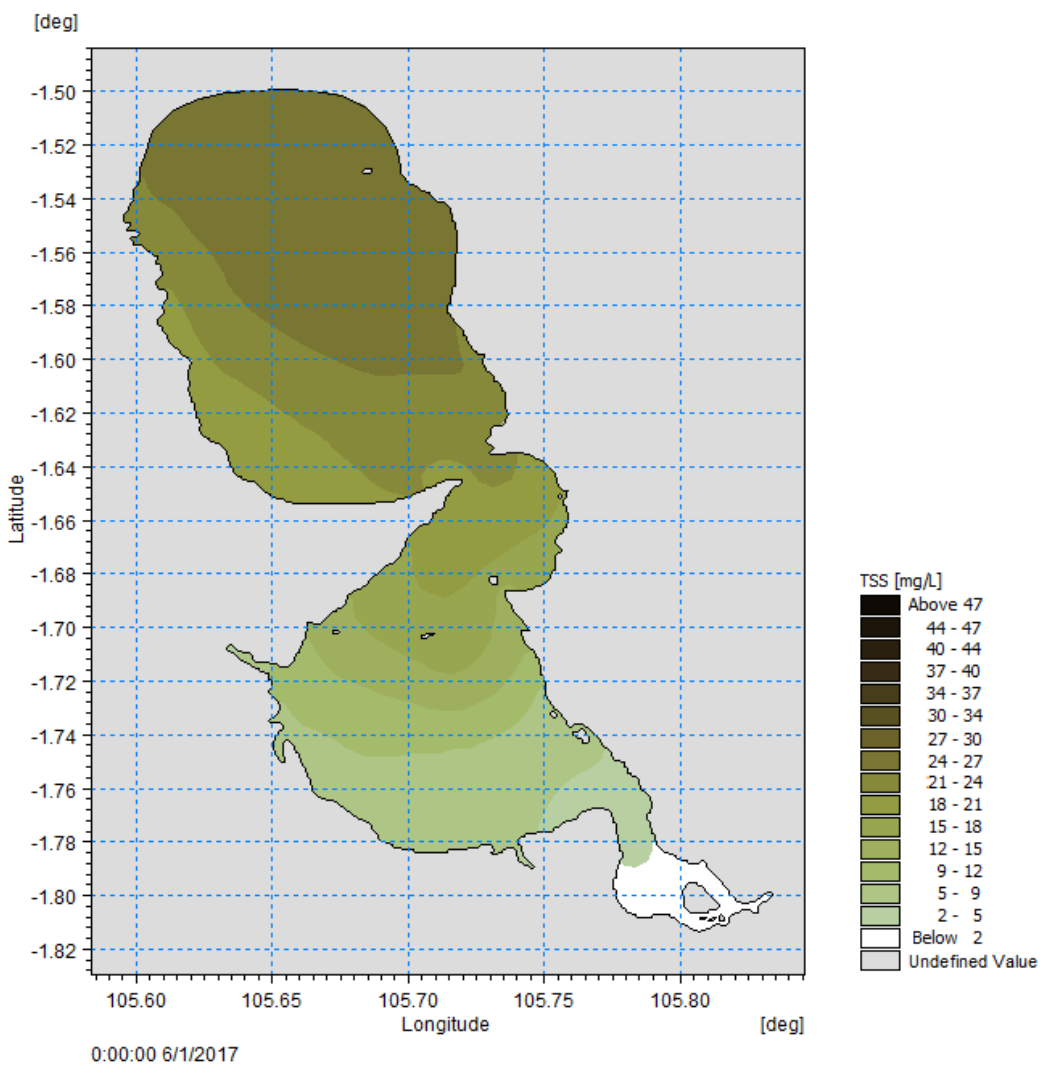

(d)

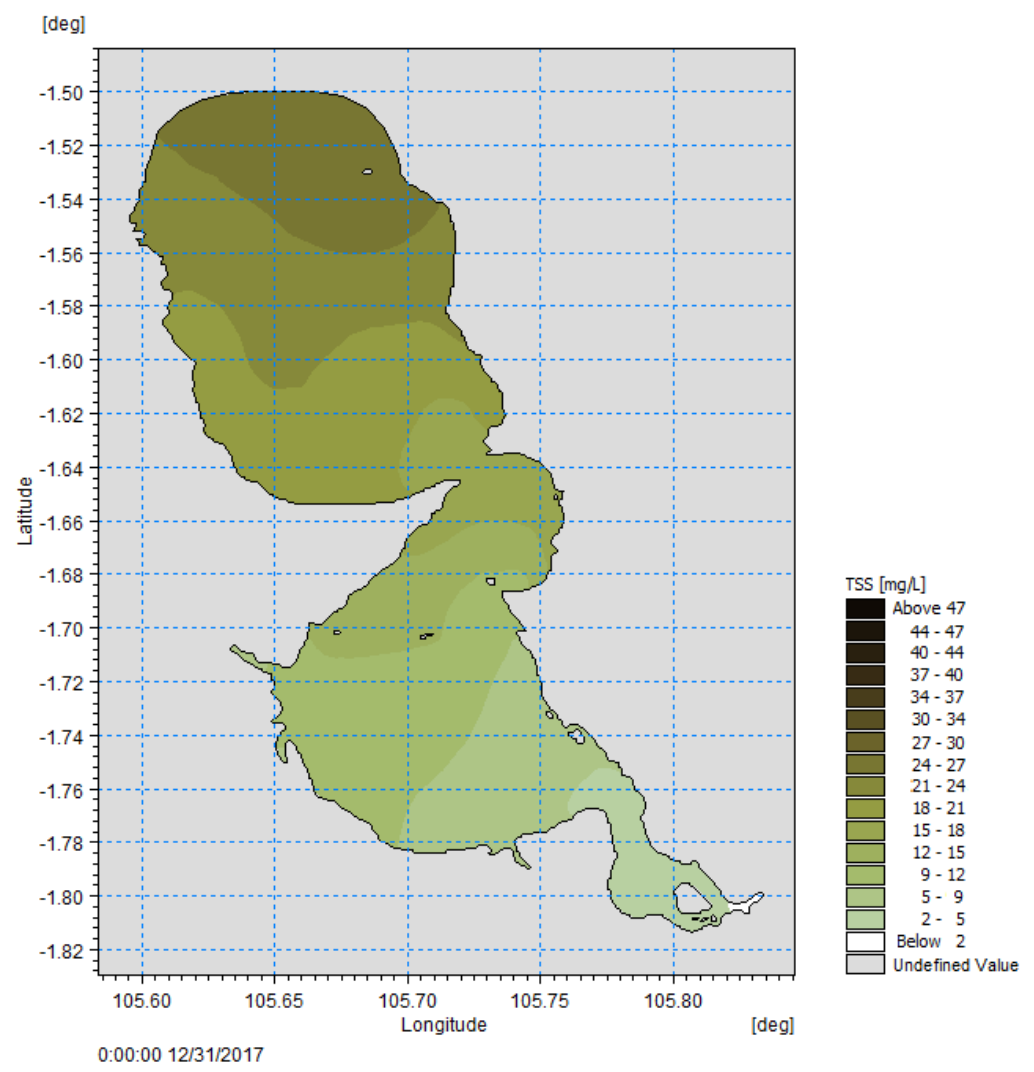

Figure 7. TSS distribution on Kelabat Bay for a) 1 month, b) 3 months, c) 6 months and d) 1 year (white colour: TSS still under sea water quality standarts). 
Table 1. TSS comparison between model and field data based on sea water quality standarts at Kelabat Bay.

\begin{tabular}{|c|c|c|c|c|c|c|c|}
\hline \multirow{3}{*}{$\begin{array}{l}\text { Code } \\
S T-1\end{array}$} & \multirow{2}{*}{\multicolumn{2}{|c|}{ Coordinat }} & \multicolumn{2}{|c|}{$T S S(m g / L)$} & \multirow{2}{*}{$\begin{array}{c}\text { Sea water quality } \\
\text { standart for } \\
\text { Marine Tourism } \\
(m g / L)\end{array}$} & \multirow{2}{*}{\multicolumn{2}{|c|}{$\begin{array}{c}\text { Sea water quality } \\
\text { standart for } \\
\text { Marine Biota } \\
(m g / L)\end{array}$}} \\
\hline & & & \multirow{3}{*}{$\begin{array}{c}\text { Field } \\
\text { Data } \\
28.0\end{array}$} & \multirow{2}{*}{$\frac{\text { Model }}{25.0}$} & & & \\
\hline & $\mathrm{S}$ & $01^{\circ} 31^{\prime} 03.64^{\prime \prime}$ & & & 20 & Coral & $: 20$ \\
\hline & $\mathrm{E}$ & $105^{\circ} 39^{\prime} 01.53^{\prime \prime}$ & & & & & \\
\hline$S T-2$ & $\mathrm{~S}$ & $01^{\circ} 36^{\prime}, 16.11^{\prime \prime}$ & 27.6 & 23.7 & & Mangrove & $: 80$ \\
\hline & $\mathrm{E}$ & $105^{\circ} 40^{\prime} 40.71^{\prime \prime}$ & & & & & \\
\hline$S T-3$ & $\mathrm{~S}$ & $01^{\circ} 38^{\prime} \quad 25.98^{\prime \prime}$ & 27.5 & 23.0 & & Seagrass & $: 20$ \\
\hline & $\mathrm{E}$ & $105^{\circ} 43^{\prime} 45.88^{\prime \prime}$ & & & & & \\
\hline
\end{tabular}

*Sea water quality standart based on Minister of the Environment Regulation number 51 2004.

penelitian Yustiani et al. (2002). Walaupun nilai TSS dari hasil model bersifat underestimate, tetapi nilai tersebut telah melewati BMAL untuk wisata bahari dan biota laut. Berdasarkan PermenLH No. 51 Tahun 2004, BMAL untuk wisata bahari, coral, dan lamun sebesar $20 \mathrm{mg} / \mathrm{L}$ sedangkan untuk mangrove sebesar $80 \mathrm{mg} / \mathrm{L}$. Kondisi ini mengindikasikan bahwa perairan Teluk Kelabat telah tercemar yang diindikasikan dengan kondisi TSS yang tinggi dan telah melewati BMAL.

\section{KESIMPULAN}

Penelitian ini menemukan bahwa proses tailing penambangan timah lepas pantai akan menyebabkan sebaran TSS yang tinggi di perairan Bangka yang ditandai dengan terlampauinya BMAL, terutama untuk aktivitas penambangan di perairan yang dangkal (kedalaman $<10 \mathrm{~m}$ ) dan dekat dengan pesisir (jarak $<2$ mil). Ketika terjadinya aktivitas tersebut, sebaran TSS akan dominan terbawa ke arah Selat Bangka; sedangkan pada wilayah Teluk Kelabat, TSS bahkan menyebar ke seluruh wilayah hingga mencapai radius sekitar 16 mil dan menyebabkan terlampauinya BMAL, sehingga akan mengancam rencana konservasi pada wilayah tersebut.

\section{UCAPAN TERIMA KASIH}

Peneliti mengucapkan terima kasih kepada beberapa pihak yang telah mendukung penelitian ini. Ucapan terima kasih kepada Kementerian Riset, Teknologi dan Pendidikan Tinggi (Kemeristekdikti) atas Hibah Penelitian Dosen Pemula. Selain itu, terima kasih kepada Lembaga Penelitian dan Pengabdian Masyarakat (LPPM), Pusat Kajian Kelautan Tropis (Pukalatrop), dan Pusat Kajian Pesisir dan Pulau-Pulau Kecil (CARSIS) Universitas Bangka Belitung. Terakhir, ucapan terima kasih kepada Badan Riset Kelautan dan Sumberdaya Manusia Kelautan dan Perikanan (BRKSDM-KP) Kementerian Kelautan dan Perikanan atas izin penggunaan lisensi MIKE21 untuk penelitian ini.

\section{DAFTAR PUSTAKA}

Ambalika, I., I. Akhrianti, A. Pamungkas, M.A. Nugraha, \& Umroh. 2019. Oceanography database development in Bangka Seas. In: Reniati et al. (eds.). Proceedings of international conference on maritime and archipelago. Atlantic Press. Bangka Belitung. 22-26 pp.

Arifin, Z. 2011. Konsentrasi logam berat di air, sedimen, dan biota di Teluk 
Kelabat, Pulau Bangka. J. Ilmu dan Teknologi Kelautan Tropis, 3(1): 104-114. https://doi.org/10.29244/jitkt.v3i1.78 39

Danish Hydraulic Institute (DHI). 2005. Hydrodynamics and transport module of MIKE 21 flow model. Scientific Documentation. DHI Water Enviromental. Denmark. 1-144 pp.

Fadli, M. \& I.M. Radjawane. 2014. Hydrodynamic modelling in Ambon Bay. Dalam: Nababan et al. (eds.). Prosiding pertemuan ilmiah nasional tahunan X ISOI 2013, Jakarta, 11-12 November 2014. 6-19 pp.

Hartoko, A., A. Febrianto, A. Pamungkas, I. Fachruddin, M. Helmi, \& Hariyadi. 2019. The myth and legend of Sadai and Gaspar Strait Bangka Belitung (Banca-Billiton) and oceanographic conditions. International J. of GEOMATE, 17(62): 212-218. https://doi.org/10.21660/2019.62.939 65

Nugroho, A.R., R. Akhwady, D. Metakaryanto, \& F. Yahya. 2016. Studi model distribusi pencemaran di pantai utara Jawa Tengah menggunakan model MIKE 21 ECOLab. $J$. Sains dan Teknologi Lingkungan, 8(2): 89-100.

https://doi.org/10.20885/jstl.vol8.iss2 . art3

Ondara, K., U.J. Wisha, \& G.A. Rahmawan. 2017. Karakteristik hidrodinamika di perairan Teluk Ambon untuk mendukung wisata selam. J. Kelautan, 10(1): 67-77. http://doi.org/10.21107/jk.v10i1.2170

Pamungkas, A. \& M.A. Farhaby. 2019. Hydro-oceanography modelling characteristic (tides, waves, and currents) in kelabat bay. In: Reniati et al. (eds.). Proceedings of international conference on maritime and archipelago. Atlantic Press. Bangka Belitung, 178-182 pp.
Pamungkas, A., I.M. Radjawane, \& I. Sofyan. 2019. Warm pool fluctuations due to the effect of ENSO in West Pacific and Indonesia Seas (study case El-Nino 2015). Proceeding of $4^{\text {th }}$ International conference on tropical and coastal region eco development. IOP Conf. Series: Earth and Environmental Science. 1-6 pp. http://doi.org/10.1088/17551315/246/1/012013

Pamungkas, A. 2018. Karakteristik parameter oseanografi (pasang-surut, arus, dan gelombang) di perairan utara dan selatan Pulau Bangka. Buletin Oseanografi Marina, 7(1): 51-58. https://doi.org/10.14710/buloma.v7i1. 19042

Pamungkas, A., I.M. Radjawane, \& Hadikusumah. 2017. Turbulent mixing in Raja Ampat Seas. Applied Mechanics and Materials, 862(1): 915.

https://doi.org/10.4028/www.scientifi c.net/AMM.862.9

Rachman, H.A., I.G. Hendrawan, \& I.D.N. Nurweda. 2016. Studi transpor sedimen di Teluk Benoa menggunakan pemodelan numerik. $J$. Kelautan, 9(2): 144-154. https://doi.org/10.21107/jk.v9i2.1617

Sachoemar, S.I. \& A. Kristijono. 2007. Pengkajian kondisi hidro-oseanografi perairan estuari Teluk Kelabat, Bangka pada musim timur. J. Alami, 10(3): 438-445.

http://ejurnal.bppt.go.id/index.php/A

LAMI_ALLM/article/view/1702

Sachoemar, S.I. \& A. Kristijono. 2005. Evaluasi kondisi lingkungan perairan estuaria Teluk Kelabat, Bangka pada Musim Timur. J. Teknik Lingkungan P3TL - BPPT, 6(3): 438-445. https://doi.org/10.29122/jtl.v6i3.350

Setyawan, W.B. \& A. Pamungkas. 2018. Perbandingan karakteristik 
oseanografi pesisir utara dan selatan Pulau Jawa: pasang-surut, arus, dan gelombang. Prosiding Seminar Nasional Kelautan dan Perikanan III 2017, Universitas Trunojoyo Madura, 7 September 2017. 191-202 pp.

Solihuddin, Tb., E.M. Sari, \& G. Kusumah. 2011. Prediksi laju sedimentasi di perairan Pemangkat, Sambas Kalimantan Barat menggunakan metode pemodelan. Buletin Geologi Tata Lingkungan, 21(3): 117-126.

Sugiyatno, D.M. 2009. Simulasi model transpor sedimen tersuspensi untuk mendukung perencanaan pelabuhan Teluk Bayur Sumatera Barat. $J$. Teknologi Lingkungan, 5(2): 46-54. http://puslit2.petra.ac.id/ejournal/inde x.php/jt1/article/view/17775

Sukarno, M. \& M. Yusuf. 2013. Kondisi hidrodinamika dan pengaruhnya terhadap sebaran parameter fisika-kimia perairan laut dari muara sungai Porong, Sidoarjo. Buletin Oseanografi Marina, 2(2): 1-6.

https://doi.org/10.14710/buloma.v2i2. 6930

Susiati, H., E. Kusratmoko, \& A. Poniman. 2010. Pola sebaran sedimen tersuspensi melalui pendekatan penginderaan jauh di perairan pesisir semenanjung Muria-Jepara. $J$. Teknologi Pengelolaan Limbah, 13(1): 72-79.

Yustiani, Y.M., D. Rusmaya, \& A. Pratama. 2012. Pengaruh aktivitas penambangan timah oleh kapal keruk terhadap kualitas parameter fisik (kekeruhan, tss, dan suhu) air laut di Teluk Kelabat Belinyu Kabupaten Bangka. Infomatek, 14(2): 75-84. http://repository.unpas.ac.id/id/eprint/ 3709

Zexun, W., S. Li, R.D. Susanto, Y. Wang, B. Fan, T. Xu, B. Sulistiyo, T.R. Adi, A. Setiawan, A. Kuswardani, \& G. Fang. 2019. An overview of 10-year observation of the South China Sea branch of the Pacific to Indian Ocean throughflow at the Karimata Strait. Acta Oceanologica Sinica, 38(4): 111. http://doi.org/10.1007/s13131019-1410-x

Received : 24 October 2019

Reviewed : 16 April 2020

Accepted : 15 July 2020 